\title{
Korelasi Paparan Benzene Dengan Gambaran Jenis Hitung Leukosit Pada Karyawan SPBU X Dan Y
}

\section{Benzene Exposure Correlation to Leukocytes Count of Employees in $\mathrm{X}$ and $\mathrm{Y}$ Gasoline Station}

\author{
Leo Pardon Sipayung ${ }^{1}$, Dwi Suryanto ${ }^{2}$, Eka Roina Megawati ${ }^{3}$ \\ ${ }^{1}$ Ilmu Keperawatan Politeknik Kesehatan YRSU DR Rusdi Medan \\ ${ }^{2}$ Bagian Biologi Fakultas MIPA Universitas Sumatera Utara \\ ${ }^{3}$ Bagian Fisiologi Fakultas Kedokteran Universitas Sumatera Utara \\ ${ }^{1}$ leopardonspy@yahoo.com, ${ }^{2}$ dwisuryanto@usu.ac.id, ${ }^{3}$ erome78@gmail.com
}

\begin{abstract}
Abstrak
Benzene $\left(\mathrm{C}_{6} \mathrm{H}_{6}\right)$ merupakan salah satu kandungan produk migas bensin yang berfungsi untuk meningkatkan nilai oktan. Paparan benzene secara kronis dapat menyebabkan penurunan produksi sel-sel darah di sumsum tulang. Penelitian ini bertujuan untuk melihat korelasi paparan benzene melalui pemeriksaan kadar ttMA (trans, trans-Muconic Acid) dalam urin dengan gambaran jenis hitung leukosit pada karyawan di Stasiun Pengisian Bahan Bakar Umum X dan Y Medan. Penelitian ini merupakan suatu penelitian deskriptif analitik dengan desain cross sectional study. Responden penelitian ini adalah karyawan beberapa SPBU di Medan $(n=43)$ dengan masa kerja $\geq 6$ bulan. Hasil penelitian menunjukkan bahwa 9 dari 43 responden memiliki kadar ttMA lebih dari $500 \mu \mathrm{g} / \mathrm{g}$ creatinin. Korelasi kadar ttMA dengan jenia hitung leukosit tidak signifikan $(\mathrm{p}>0,05)$, ttMA berkorelasi negatif dengan jenis hitung leukosit. Kesimpulan penelitian ini adalah bahwa perbedaan rata-rata kadar ttMA pada masa kerja $\leq 1$ tahun dan masa kerja $>1$ tahun tidak signifikan $(\mathrm{p}=0,45)$, dan perbedaan rata-rata kadar ttMA pada subjek yang merokok dan tidak merokok tidak signifikan $(\mathrm{p}=0,559)$.
\end{abstract}

Kata Kunci: benzene, ttMa, leukosit

\begin{abstract}
Benzene $\left(\mathrm{C}_{6} \mathrm{H}_{6}\right)$ is one of the migas content of gasoline that serves to enhance the octane value. Chronic exposure to benzene decrease the production of blood cells in the bone marrow. The aim of this study is to find the correlation of benzene exposure through the examination of ttMA (trans, trans-Muconic Acid) levels in urine to the leukocytes counts of employees in the $X$ and $Y$ Gasoline station Medan. This study is a descriptive analytical study with cross sectional design. The subjects were employees of Gasoline Station in Medan $(n=43)$ with $\geq 6$ months duration of working. The results showed that 9 of 43 subjects had ttMA levels more than $500 \mathrm{mg} / \mathrm{g}$ creatinine. The Correlation of ttMA levels with leukocytes counts were not significant ( $p>0.05)$, ttMA were negatively correlated with leukocytes counts. We Conclude that the difference of ttMA levels in average $\leq 1$ year duration of working and $>1$ year duration of working was not significant $(p=0,451)$. The difference of ttMA levels in average for the subjects who smoke and not smoke was not significant $(p=0,559)$.
\end{abstract}

Keywords: benzene, ttMA, leukocytes 
Journal of Healthcare Technology and Medicine Vol. 6 No. 2 Oktober 2020

Universitas Ubudiyah Indonesia

e-ISSN : 2615-109X

\section{PENDAHULUAN}

Bensin mengandung senyawa benzene $\left(\mathrm{C}_{6} \mathrm{H}_{6}\right)$ yang berfungsi untuk meningkatkan nilai oktan dalam bahan bakar bensin (Pudyoko, 2010). Penggunaan benzene dalam bahan bakar bensin menimbulkan berbagai masalah, mulai dari masalah limbah, pencemaran udara, hingga masalah pengaruh penggunaan bahan berbahaya bagi kesehatan pekerja dan manusia di lingkungan sekitar (Tanasorn et al, 2012).

Paparan benzene secara kronis dapat menyebabkan penurunan produksi sel-sel darah (Shan et al, 2014). Benzene juga dapat sampai ke sumsum tulang dan merusak produksi sel-sel darah sehingga orang yang terpapar benzene dapat mengalami penyakit-penyakit yang berkaitan dengan penurunan produksi sel-sel darah di sumsum tulang (Marco et al, 2010).

Beberapa penelitian mengindikasikan hubungan kuantitas antara paparan benzene secara inhalasi dengan trans, trans-muconic acid (ttMA) sebagai biomarker terhadap paparan benzene (Tunsaringkarn et al, 2012). Trans, trans-Muconic Acid (ttMA) merupakan metabolit minor dari benzene yang dapat digunakan sebagai indikator biologi untuk paparan benzene (Zuliyawan, 2010).

Terjadinya abnormalitas pada sistem hematopoietik yaitu jenis hitung leukosit akibat paparan benzene menjadi perhatian utama (Eni dkk, 2016). Pemeriksaan dan pengujian secara laboratorium yang dilakukan terhadap pekerja yang beresiko terpapar benzene mencakup jenis hitung leukosit (Jorunn, 2011).

Hati merupakan organ yang menjadi tempat utama dalam metabolisme benzene, dimana akan dihasilkan beberapa metabolit (Scoot et al, 2012). Setelah masuk ke dalam aliran darah, benzene akan beredar ke seluruh tubuh dan disimpan sementara di dalam jaringan lemak dan sumsum tulang, kemudian akan dikonversi menjadi metabolit di dalam hati dan sumsum tulang (Martinez et al, 2010). Setelah kurang lebih 48 jam paparan, sebagian besar hasil metabolisme akan keluar melalui urin (Jorunn, 2011).

Di dalam hati benzene pertama sekali dioksidasi oleh katalis enzyme cytochrome P450 monooksigenase menjadi benzene oksida (Giovanna et al, 2012). Setelah reaksi ini, maka terbentuklah beberapa metabolit sekunder baik secara enzymatic dan non enzymatic (Luoping et al, 2010). Setelah benzene dimetabolisme di hati dan menghasilkan metabolit-metabolit sekunder, maka metabolit-metabolit tersebut kemudian dibawa ke sumsum tulang dimana toksisitas benzene terlihat melalui metabolit reaktif benzene (Marthyn et al,2010; Jeffrey et al, 2013). 
Journal of Healthcare Technology and Medicine Vol. 6 No. 2 Oktober 2020

Universitas Ubudiyah Indonesia

e-ISSN : 2615-109X

trans, trans-Muconic Acid (ttMA) dapat digunakan sebagai indikator yang lebih sensitif dan spesifik untuk biomonitoring biologi, terutama untuk paparan benzene dengan konsentrasi rendah (Marisa et al, 2010; Junchieh et al, 2013). Penelitian ini bertujuan untuk melihat paparan benzene melalui pemeriksaan kadar ttMA dalam urin pada karyawan di SPBU X dan Y, yaitu korelasinya terhadap gambaran jenis hitung leukosit untuk dapat diketahui dan dicegah kemungkinan adanya gangguan sistem hematopoietik terkait leukosit akibat paparan benzene.

\section{METODE PENELITIAN}

Jenis penelitian yang digunakan adalah deskriptif analitik dengan desain cross sectional study. Populasi penelitian adalah seluruh karyawan SPBU X dan Y di kota Medan, dengan jumlah responden sebanyak 43 orang berusia 18-36 tahun, yang diperoleh dengan cara consecutive sampling. Kriteria inklusi adalah responden yang bekerja di atas 6 bulan, tidak memiliki riwayat penyakit hematologi dan tidak mengkonsumsi obat-obatan yang mempengaruhi sistem hematopoietik. Pengambilan sampel darah post-shift dilakukan untuk kemudian dilakukan pemeriksaan jenis hitung leukosit. Pemeriksaan jenis hitung leukosit dilakukan menggunakan Hematology Analyzer ABX Micros 60 dengan prinsip kerja berdasarkan spesifikasi ukuran sel yang melewati filter dengan memakai tegangan listrik untuk sekali pembacaan.

Sampel urin post-shift diambil untuk pemeriksaan kadar trans, trans-Muconic Acid (ttMA). Pemeriksaan ttMA dilakukan mengunakan High Performance Liquid Chromatography (HPLC). Urine post-shift sebanyak $250 \mathrm{ml}$, dimasukkan ke dalam botol polyethilene, kemudian ditambahkan thymol secukupnya. Sampel urine disimpan dengan pengaturan suhu $4^{0} \mathrm{C}$. Sebelum melakukan analisa ttMA, terlebih dahulu dilakukan analisa creatinin urin. Sebanyak $1 \mathrm{ml}$ sampel urin dicampur dengan $80 \mu \mathrm{L}$ HCL $6 \mathrm{~N}$, kemudian ditambahkan $\mathrm{NaCl}$ sebanyak 0,3 gram. Kemudian ditambahkan ethyl asetat sebanyak $4 \mathrm{ml}$, kemudian di sentrifugasi dengan kecepatan 100 kali gravitasi selama 5 menit. Sebanyak $200 \mu \mathrm{L}$ fasa organik ditransfer ke lapisan atas botol HPLC dan dibiarkan selama 30 menit sampai mengering, sambil dipanaskan menggunakan air dengan suhu $30^{\circ} \mathrm{C}$, kemudian dibilas dengan menggunakan nitrogen yang dialirkan. Standar kerja disiapkan dengan rentang 10-1000 $\mu \mathrm{g} / \mathrm{ml}$ dengan pengenceran hipuric acid yang digabungkan dengan larutan stok menggunakan urin sintesis. Setelah itu masingmasing standar, sampel dan kontrol di ambil sebanyak $10 \mu \mathrm{L}$ kemudian di injeksikan ke HPLC untuk menentukan ketinggian puncak kadar ttMA di dalam sampel. Setiap gram analit dihitung dengan membandingkan pada setiap gram creatinin $\left(\mathrm{C}_{\mathrm{R}}=\right.$ gr creatinin/L urin $)$ dalam sampel 
Journal of Healthcare Technology and Medicine Vol. 6 No. 2 Oktober 2020

Universitas Ubudiyah Indonesia

e-ISSN : 2615-109X

urin. Analisa data akan menggunakan SPSS ver.20.0. Analisis normalitas dan homogenitas data dilakukan menggunakan uji Shapiro-Wilk. Analisis korelasi diuji menggunakan Spearman Correlation dengan batas kemaknaan yang ditetapkan sebesar 5\%. Untuk mengetahui perbandingan rata-rata kadar ttMA pada kelompok dengan masa kerja $\leq 1$ tahun dan $>1$ tahun, juga perbandingan rata-rata kadar ttMA pada kelompok merokok dan tidak merokok, dilakukan dengan uji Mann-Whitney dengan batas kemaknaan yang ditetapkan sebesar 5\%. Penyajian data dalam bentuk tabel dan disertai narasi.

\section{HASIL DAN PEMBAHASAN}

A. Hasil

Karakteristik subjek penelitian di kategorikan berdasarkan jenis kelamin, usia, petugas bagian, masa kerja dan kebiasaan merokok. Subjek yang terlibat dalam penelitian ini lebih banyak berjenis kelamin laki-laki, berusia antara 18 - 24 tahun, lebih banyak petugas operator, masa kerja di atas 1 tahun, dan lebih banyak yang tidak merokok. Karakteristik subjek penelitian ditunjukkan pada Tabel 1.

Tabel. 1 Karakteristik Subjek Penelitian

\begin{tabular}{|c|c|c|}
\hline Karakteristik Subjek & Jumlah (n) & Persentase $(\%)$ \\
\hline \multicolumn{3}{|l|}{ Jenis Kelamin } \\
\hline Laki-laki & 25 & 58,13 \\
\hline Perempuan & 18 & 41,86 \\
\hline \multicolumn{3}{|l|}{ Usia } \\
\hline $18-24$ & 31 & 72,10 \\
\hline $25-30$ & 8 & 18,60 \\
\hline $31-36$ & 4 & 9,30 \\
\hline \multicolumn{3}{|l|}{ Petugas } \\
\hline Administrasi & 8 & 18,60 \\
\hline Operator & 35 & 81,40 \\
\hline \multicolumn{3}{|l|}{ Masa Kerja } \\
\hline$\leq 1$ tahun & 13 & 30,23 \\
\hline$>1$ Tahun & 30 & 69,77 \\
\hline \multicolumn{3}{|l|}{ Kebiasaan Merokok } \\
\hline Merokok & 11 & 25,58 \\
\hline Tidak merokok & 32 & 74,42 \\
\hline
\end{tabular}

Sebagian besar responden berjenis kelamin laki-laki (58,1\%), dengan kelompok umur 18-24 tahun $(72,1 \%)$, bertugas sebagai operator pengisian $(81,4 \%)$, dengan masa kerja lebih dari 1 tahun $(69,7 \%)$, dan tidak merokok $(74,4 \%)$. 
Journal of Healthcare Technology and Medicine Vol. 6 No. 2 Oktober 2020

Universitas Ubudiyah Indonesia

e-ISSN : 2615-109X

Tabel. 2 Gambaran kadar ttMA urin responden

\begin{tabular}{ccccc}
\hline & & Rendah & Tinggi & Jumlah \\
\cline { 3 - 5 } trans,trans-Muconic Acid & $\mathrm{n}$ & 34 & 9 & 43 \\
(ttMA) & $\%$ & 79,06 & 20,93 & 100 \\
\hline
\end{tabular}

Hasil penelitian menunjukkan 9 responden (20,9\%) dari 43 memiliki kadar ttMA dalam urin lebih dari $500 \mu \mathrm{g} / \mathrm{g}$ creatinin.

Tabel. 4 Gambaran jenis hitung leukosit

\begin{tabular}{cccccc}
\hline & & Rendah & Tinggi & Normal & Jumlah \\
\cline { 3 - 6 } Leukosit & $\mathrm{n}$ & - & 2 & 41 & 43 \\
& $\%$ & - & 4,65 & 95,35 & 100 \\
\hline
\end{tabular}

Hasil penelitian menunjukkan hanya 2 responden (4,65\%) dari 43 yang memiliki jenis hitung leukosit tinggi.

Tabel. 3 Hasil uji korelasi ttMA dengan CBC

\begin{tabular}{ccc}
\hline & & Leukosit \\
ttMA & Koefisien korelasi & $-0,065$ \\
& $(\mathrm{r})$ & \\
& $p$-value & 0,680 \\
\hline
\end{tabular}

Hasil uji statistik menunjukkan ttMA urin memiliki korelasi negatif dengan parameter leukosit dan diperolah nilai $\mathrm{p}>0,05$.

Tabel. 4 Uji perbandingan rata-rata kadar ttMA berdasarkan masa kerja

\begin{tabular}{cccccc} 
& & N & Mean & SD & p-value \\
\cline { 3 - 7 } Masa Kerja & $\leq 1$ tahun & 13 & 1177,30 & 2107,61 & \\
& $>1$ Tahun & 30 & 331,03 & 697,50 & 0,451
\end{tabular}


Journal of Healthcare Technology and Medicine Vol. 6 No. 2 Oktober 2020

Universitas Ubudiyah Indonesia

e-ISSN : 2615-109X

Tabel 4 menunjukkan bahwa bahwa perbedaan rata-rata kadar ttMA pada masa kerja $\leq$ 1 tahun dan masa kerja $>1$ tahun adalah tidak signifikan $p=0,451(p>0,05)$.

Tabel. 5 Uji kadar ttMA antara subjek yang merokok dan tidak merokok.

\begin{tabular}{cccccc}
\hline & & n & Mean & SD & p-value \\
\cline { 3 - 6 } Kebiasaan & Merokok & 11 & 923,63 & 2108,70 & \\
Merokok & $\begin{array}{c}\text { Tidak } \\
\text { Merokok }\end{array}$ & 32 & 471,12 & 946,40 & 0,559 \\
\hline
\end{tabular}

Tabel 4 menunjukkan perbedaan rata-rata kadar ttMA pada merokok dan tidak merokok adalah tidak signifikan $p=0,559(p>0,05)$.

\section{B. PEMBAHASAN}

Penelitian yang dilakukan terhadap 43 responden yang bekerja di SPBU X dan Y dengan melakukan pemeriksaan kadar ttMA dalam urin dan pemeriksaan jenis hitung leukosit didapatkan adanya hasil yang bervariasi. Hasil analisis korelasi kadar ttMA dengan parameter jenis hitung leukosit diperoleh tidak signifikan ( $p>0,05)$ setelah diuji secara statistik. Hal ini disebabkan jumlah kadar ttMA yang sangat berbeda (sangat rendah dan sangat tinggi) satu sama lain.

Kadar ttMA dengan parameter jenis hitung leukosit didapatkan arah korelasi negatif (berhubungan terbalik), artinya peningkatan kadar ttMA dalam urine tidak diikuti dengan peningkatan nilai jenis hitung leukosit.

Pada penelitian ini nilai jenis hitung leukosit didapatkan tidak terjadi penurunan yang signifikan. Sementara penelitian sebelumnya yang dilakukan oleh Jorrun et al tahun 2011 terhadap pekerja pertambangan minyak mentah, menemukan adanya penurunan leukosit pada pekerja yang terpapar dengan benzene. Hal ini disebabkan pekerja tersebut berada di lokasi pertambangan minyak selama 24 jam sehingga terpapar oleh benzene secara terus menerus (Jorrun et al, 2011).

Hasil penelitian pada pemeriksaan kadar ttMA dalam urin terhadap 43 responden didapatkan 9 diantaranya memiliki kadar ttMA lebih dari batas normal ( $>500 \mu \mathrm{g} / \mathrm{gr}$ creatinine). Peningkatan kadar ttMA pada 9 responden tersebut diduga terjadi akibat beberapa faktor, diantaranya riwayat pekerjaan sebelumnya dan kebiasaan mengkonsumsi makanan yang 
Journal of Healthcare Technology and Medicine Vol. 6 No. 2 Oktober 2020

Universitas Ubudiyah Indonesia

e-ISSN : 2615-109X

mengandung asam sorbat tinggi. Diketahui dari sembilan (9) responden dengan kadar ttMA tinggi satu orang diantaranya memiliki riwayat pekerjaan sebelumnya yang juga terpapar dengan benzene, beberapa diantaranya sudah bekerja di atas 1 tahun sebagai karyawan SPBU. Luipong et al tahun 2010 mengatakan setelah benzene terdistribusi ke dalam aliran darah, maka sebagian besar benzene akan terdistribusi ke dalam jaringan lemak, hal ini disebabkan karena benzene bersifat lipofilik yang menyebabkan benzene terakumulasi di dalam tubuh, tidak diketahui berapa lama akumulasi benzene di dalam tubuh. Kemudian Marthyn et al tahun 2010 juga mengatakan jumlah benzene dalam jaringan lemak, sumsum tulang dan urin 20 kali lebih banyak dibandingkan dengan jumlah benzene yang terdapat di dalam aliran darah.

Jumlah rata-rata benzene yang masuk ke dalam tubuh secara inhalasi, akan dieliminasi sekitar 30\% dari seluruh jumlah paparan. Junchiech et al tahun 2013 mengatakan hal tersebut berlangsung reversibel sehingga benzene tidak sempat mengalami reaksi metabolisme di dalam tubuh dan benzene akan dieksresikan oleh paru-paru dan di buang melalui ekshalasi. Hal inilah yang menjadi alasan mengapa dari seluruh responden, 34 diantaranya kadar ttMA dalam urine didapatkan sangat kecil, yakni $<500 \mu \mathrm{g} / \mathrm{gr}$ creatinine. Selain dari pada itu manajemen SPBU X dan Y menerapkan sistem jadwal kerja yang cukup baik, yakni SPBU X dengan dua shift kerja (pagi-sore) menerapkan jadwal kerja 4-1, artinya karyawan bekerja 4 hari dan libur 1 hari. Kemudian SPBU Y dengan 3 shift kerja (pagi-sore-malam) menerapkan jadwal kerja 3-1, artinya karyawan bekerja 3 hari dan libur 1 hari, dan durasi setiap shift kerja dari kedua SPBU adalah 8 jam kerja. Hal ini memungkinkan responden tidak terpapar oleh benzene secara terus menerus sehingga kadar ttMA di dalam urin ditemukan sangat kecil.

\section{KESIMPULAN}

Berdasarkan hasil analisis data dan pembahasan mengenai korelasi paparan benzene dengan gambaran jenis hitung leukosit pada karyawan SPBU X dan Y maka dapat dibuat kesimpulan bahwa ada korelasi ttMA dalam urine dengan penurunan nilai jenis hitung leukosit, yang ditunjukkan dengan arah korelasi negatif, yaitu peningkatan kadar ttMA urin menyebabkan penurunan nilai dari parameter jenis hitung leukosit. rata-rata kadar ttMA pada masa kerja $\leq 1$ tahun dan masa kerja $>1$ tahun tidak signifikan $(\mathrm{p}=0,45)$, dan perbedaan ratarata kadar ttMA pada subjek yang merokok dan tidak merokok tidak signifikan $(p=0,559)$.

\section{SARAN}

Dari penelitian ini disarankan secara umum kepeda pemerintah dan secara khusus kepada pengelola manajemen Stasiun Pengisian Bahan Bakar Umum di seluruh Indonesia agar 
Journal of Healthcare Technology and Medicine Vol. 6 No. 2 Oktober 2020

Universitas Ubudiyah Indonesia

e-ISSN : 2615-109X

menfasilitasi mekanisme kesehatan keselamatan kerja bagi karyawan di SPBU tanpa mengabaikan prinsip kerja yaitu "Senyum, Salam, Sapa" yang dapat berupa penggunaan alat pelindung diri yaitu masker penutup hidung dan mulut, dan sarung tangan agar tidak terjadi paparan benzene secara kontak dengan kulit dan inhalasi. Di SPBU dapat digunakan fasilitas berupa operator audio, banner, atau poster/ spanduk yang berfungsi untuk menyampaikan senyum, salam dan sapa kepada konsumen agar karyawan bisa menggunakan alat pelindung sebagai cara pencegahan terhadap paparan benzene tetapi prinsip kerja tetap tidak diabaikan.

\section{DAFTAR PUSTAKA}

Pudyoko, S. Hubungan Pajanan Benzene dengan kadar Phenol dalam Urin dan Gangguan Sistem Hematopoietik pada Pekerja Instalasi BBM [Tesis]. Semarang: Universitas Diponegoro; 2010.

Shan, P.T, Erin, E.F, Jerry, D.R, Judy, K.W, Louis, C.W, Robin, P.D. A hematology surveillance study of petrochemical workers exposed to benzene. Regulatory Toxicology and Pharmacology; 2014;40:67-73.

Tunsaringkarn, T, Soogarun, S, Palasuwan, A. Occupational Exposure to Benzene and Changes in Hematological Parameters and Urinary Trans, Trans-Muconic Acid. International Journal of Occupational and Environmental Medicine; 2012;4:45-49.

Zuliyawan. Analisis Resiko Kesehatan Pajanan Benzene Melalui Penentuan Level Trans, Trans-Muconic Acid Dalam Urin Pada Karyawan di SPBU 'X' Jakarta Utara; 2010.

Jorunn, K. Benzene Exposure and Hematological Effect among Offshore Workers Exposed to Crude Oil [Dissertation] Norway: Degree Philosophiae Doctor (PhD) at the University of Bergan; 2011.

Eni, M, Suhartono, Nurjazuli. Hubungan Antara kadar Fenol dalm Urine Dengan Kadar Hb, Eritrosit, Trombosit dan Leukosit (Studi Pada Tenaga Kerja di Industri Karoseri CV Laksana Semarang. Jurnal Kesehatan Indonesia. 2016;5(1):1-5.

Scoot, M.A, Juergan, A, Peter, J.B, Michael, F.H, Raegan, B.O, Steven, H.R. and A Robert, S. The use of biomonitoring data in exposure and human health risk assessment: benzene case study. Critical Reviews in Toxicology. 2012;43(2):119-153.

Martinez, M, Maldonado, V, Ortega, A, Melendez-Zajgla, J, Albores, A. Benzene metabolites induce apoptosis in lymphocytes. Experimental and Toxicologic Pathology. 2010;58:6570. 
Journal of Healthcare Technology and Medicine Vol. 6 No. 2 Oktober 2020

Universitas Ubudiyah Indonesia

e-ISSN : 2615-109X

Giovanna, S, Salvatore, S, Francesco, C, Daniela, S, Paolina, Q, Mariella, C, Mario, B, Antonella, S, Sebastiano, G. Increased serum level of advanced oxidation protein products and glycation end products in subjects exposed to low-dose benzene. International Journal of Hygiene and Environmental Health. 2012;215:389-392.

Marthyn, T.S. Advances in Understanding Benzene Health Effects and Susceptibility. The Annual Review of Public Health. 2010;31:133-148.

Luoping, Z, Cliona, M.M, Nathniel, R, Guilan, L, Zhiying, J, Roel, V, Alan, E.H., Xuefeng, R, Min, S, Stephen, M.R, Matthew, N, Christine, F.S, Songnian, Y., Christopher, V, Stephen, J.C, Marthyn, T.S. and Qing, L. Systems biology of human benzene exposure. Chemical Biological Interactions. 2010;184(1-2):86-93.

Jeffrey, S.K, Brent, d.K, Brent, F. and dennis, J.P. A Clibrated Human PBPK Model for Benzene Inhalation with Urinary Bladder and Bone Marrow Compartments. Risk Analysis. 2013;33(7):1237-1251.

Junchieh, J.T, Kam-Meng, T, Alissa, K.G, Harvey, P, William, N.R. Aryl Hydrocarbon Receptor and Lung Cancer. Anticancer Res. 2013;33(4):1247-1256.

Tanasorn, T, Panthira, K, Wattasit, S, Anusorn,R. and Kalaya, Z. Benzene Exposure and its Association with Sickness Exhibited in Gasoline Station Workers. Columbia International Publishing: Journal of Environmental Pollution and Solutions. 2012;1:1-8. Marco, V., Kenneth, J.R., Chaterine, M.C., Antonella, s., Andrea, C., Luisa, G., Giuseppe, M., Enrica, F., Sara, F., Sergio, T., Dario, C., Gianfranco, D.G., Alessandro, M., Giovanni, P., Paolo, P., Carlotta, M. Leukemia risk in children exposed to benzene and $\mathrm{PM}_{10}$ from vehicular traffic: a case-control study in an Italian population. Europe Journal Epidemiology. 2010.27:781-790.

Marisa, L.K., Ken, M.U., Julie, M.P., Amanda, M.B., Dennis, J.P., Lindsay, E.B., Richard, H.G. and Shannon, H.G. Benzene exposure in refinery workers: ExxonMobil Joliet, Illionis, USA (1977-2006). Toxicology and Industrial Health. 2010.26(10):671-690. 